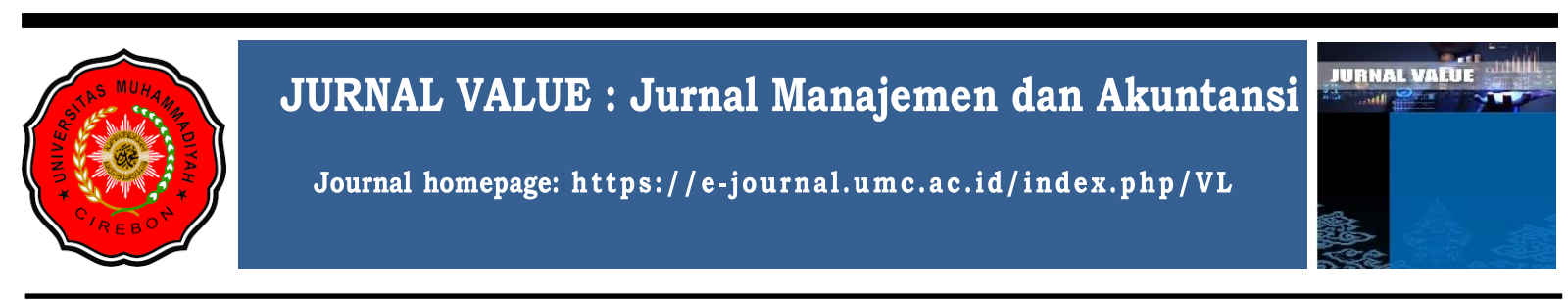

\title{
PENGARUH RELIGIUSITAS, KOMPETENSI, DAN BUDAYA ORGANISASI TERHADAP KOMITMEN ORGANISASIONAL (Pada PDAM Tirta Moedal Jl. Kelud Raya Kota Semarang)
}

\author{
Ima Nurshilasari ${ }^{1}$ \\ Tristiana Rijanti ${ }^{2 *}$ \\ ${ }^{1}$ Fakultas Ekonomika dan Bisnis, Universitas Stikubank (UNISBANK) Semarang \\ Email : imashilasari99@gmail.com \\ ${ }^{2}$ Fakultas Ekonomika dan Bisnis, Universitas Stikubank (UNISBANK) Semarang \\ *Corresponden Author Email : tristianar@edu.unisbank.ac.id
}

Diterima : 5 Juli 2021

Direvisi : 16 Juli 2021

Dipublikasikan : 23 Agustus 2021

\begin{abstract}
Abstrak
Keberhasilan manajemen organisasi, salah satunya ditentukan oleh keberhasilan manajemen dalam menumbuhkan komitmen organisasional. Seberapa jauh komitmen organisasional karyawan terhadap organisasi akan sangat menentukan pencapaian tujuan organisasi. Penelitian ini bertujuan untuk menguji dan menganalisis pengaruh Religiusitas, Kompetensi, dan Budaya Organisasi terhadap Komitmen Organisasional di PDAM Tirta Moedal Jl. Kelud Raya Kota Semarang. Teknik pengumpulan data dilakukan dengan wawancara, kuesioner, dan observasi. Populasi pada penelitian ini adalah seluruh karyawan muslim yang berjumlah 222 karyawan. Dengan metode Slovin maka jumlah sampel berjumlah 100 karyawan. Teknik pengumpulan sampel menggunakan simple random sampling. Alat analisis yang digunakan adalah regresi linier berganda dengan bantuan program SPSS 23. Hasil penelitian menunjukkan bahwa : (1) Religiusitas tidak berpengaruh terhadap Komitmen Organisasional (2) Kompetensi berpengaruh positif dan signifikan terhadap Komitmen Organisasional (3) Budaya Organisasi berpengaruh positif dan signifikan terhadap Komitmen Organisasional.
\end{abstract}

Kata Kunci : Religiusitas, Kompetensi, Budaya Organisasi, dan Komitmen Organisasional

\section{PENDAHULUAN}

Setiap perusahaan didirikan untuk mencapai tujuan yang akan dicapai sesuai dengan visi misinya. Untuk mencapai tujuan tersebut perlu adanya fungsi manajemen yang baik. Kesuksesan sebuah perusahaan tidak terlepas dari kemampuan terbaik yang diberikan oleh para karyawannya. Namun, tidak semua karyawan di suatu perusahaan memiliki komitmen yang tinggi terhadap perusahaannya. Komitmen organisasional didefinisikan sebagai kekuatan yang bersifat relative dari individu dalam mengidentifikasikan keterlibatan dirinya kedalam bagian organisasi, yang dicirikan oleh penerimaan nilai dan tujuan organisasi, kesediaan berusaha demi organisasi dan keinginan mempertahankan keanggotaan dalam organisasi (Robbins \& Judges, 2011)

Organisasi membutuhkan pegawai yang berniat untuk memelihara keanggotaannya di dalam organisasi dengan sepenuh hati. Komitmen pegawai pada organisasi tidak terjadi demikian saja, tetapi melalui proses yang cukup panjang dan bertahap. Bagi karyawan, memiliki komitmen yang tinggi dapat memberikan keuntungan bagi dirinya sendiri, seperti memperluas kesempatan untuk dipromosikan, menurunkan kemungkinan di demosikan, serta membuat pegawai semakin berpengalaman dalam bidangnya, sedangkan komitmen karyawan yang rendah memiliki dampak negatif (Luthans, 2011).

Disamping komitmen organisasional ada indikasi bahwa sikap religiusitas yang ada pada setiap individu, bisa sebagai batasan ketika melakukan persaingan di dunia kerja (Lajim et al, 2015). Beberapa 
organisasi dan pemimpinnya, mempunyai sebuah kepercayaan bahwa pandangan spiritual akan mendorong sikap kerja, praktik-praktik penyelesaian stres, dan etika kerja kolektif yang lebih baik. Sehingga, apabila religiusitas seseorang meningkat, maka berdampak pada sikap kerja yaitu komitmen karyawan tersebut untuk tetap tinggal diperusahaan akan meningkat serta cenderung berperilaku positif pula. Namun karakter karyawan di perusahaan yang sebagian besar sarjana sudah pada tingkat matang dalam beragama, sehingga tidak lagi menjadi faktor yang berpengaruh terhadap komitmen organisasional. Karena faktor religiusitas adalah hubungan mereka dengan Tuhannya. Hal ini sesuai dengan penelitian (Isnaini, 2018) yang menyatakan religiusitas tidak memiliki pengaruh signifikan terhadap komitmen organisasional.

Salah satu faktor yang dapat mempengaruhi komitmen organisasional yaitu kompetensi. Kompetensi adalah perpanduan pengetahuan, keterampilan, sikap dan karakteristik pribadi lainnya yang diperlukan untuk mencapai keberhasilan dalam sebuah pekerjaan, yang bisa diukur dengan menggunakan standar yang telah disepakati yang dapat ditingkatkan melalui pelatihan dan pengembangan (Marwansyah, 2016). Menurut (Wibowo, 2012) kompetensi merupakan kemampuan melaksanakan pekerjaan atau tugas yang didasari ketrampilan maupun pengetahuan dan didukung oleh sikap kerja yang ditetapkan oleh pekerjaan. Karyawan yang sudah mempunyai kompetensi yang baik, maka perusahaan akan mempertahankan karyawan untuk tetap bekerja dengan memberikan gaji, tunjangan, dan lain-lain yang sesuai dengan kompetensinya. Timbal balik yang sesuai antar perusahaan dengan karyawan yang bekerja, membuat karyawan akan berkomitmen terhadap perusahaan tempat dia bekerja sekarang (Fadli, 2012). Hasil penelitian terdahulu oleh beberapa peneliti antara lain (Adhi, 2016) dan dengan menggunakan 235 sampel menggunakan konsep komitmen organisasional Sriekaningsih (2015) menunjukkan bahwa kompetensi berpengaruh secara positif dan signifikan terhadap komitmen organisasional sedangkan hasil yang berbeda ditunjukkan oleh (Puji, 2012) yang menunjukkan bahwa kompetensi tidak berpengaruh signifikan terhadap komitmen organisasional. Sampel dari penelitian ini adalah 200 responden, dalam penelitian ini konsep komitmen organisasional menggunakan pendapat (Robbins S. , 2008).

Budaya organisasi juga mempengaruhi komitmen organisasional. Menurut (Luthans, 2011 : 137) budaya organisasi adalah pola pemikiran dasar yang diajarkan kepada personel baru sebagai cara untuk merasakan, berfikir, dan bertindak secara benar dari hari- kehari. Budaya organisasi sangat berpengaruh terhadap perilaku para anggota organisasi karena sistem nilai dalam budaya organisasi dapat dijadikan acuan perilaku manusia dalam organisasi yang berorientasi pada pencapaian tujuan atau hasil kinerja yang ditetapkan, sehingga jika budaya organisasi baik, maka tidak mengherankan jika anggota organisasi adalah orang-orang yang baik dan berkualitas (Sunhaji, 2014). Berdasarkan pendapat para ahli di atas budaya organisasi dapat dinyatakan sebagai nilai dalam organisasi yang dapat digunakan sebagai pedoman anggota dalam melaksanakan tugasnya. Hasil penelitian dilakukan (Putu, 2019) bahwa ada hubungan positif antara budaya organisasi terhadap komitmen organisasional. Sampel dari penelitian ini adalah 100 PNS di Dinas Tenaga Kerja dan ESDM Provinsi Bali, dalam penelitian ini konsep komitmen organisasional menggunakan pendapat (Robbins, 2008).

Berdasarkan prasurvey yang dilakukan kepada 20 karyawan menyatakan bahwa komitmen organisasional di PDAM Tirta Moedal Jl. Kelud Raya Kota Semarang belum bisa dikatakan optimal. Karena cukup banyak karyawan yang mengajukan resign atau pengunduran diri, adanya karyawan yang meninggalkan tempat kerja pada saat jam kerja berlangsung, dan banyak karyawan merasa bahwa perusahaan tidak berjasa untuk dirinya (Sumber : wawancara atau hasil pra survey tahun 2021). Dengan kondisi tersebut menunjukkan bahwa karyawan tidak memiliki komitmen yang tinggi pada perusahaan. Berdasarkan latar belakang di atas, maka menarik untuk diteliti "Pengaruh Religiusitas, Kompetensi, dan Budaya Organisasi terhadap Komitmen Organisasional pada PDAM Tirta Moedal Jl. Kelud Raya Kota Semarang".

\section{KAJIAN PUSTAKA}

\section{KOMITMEN ORGANISASIONAL}

Menurut Allen dan Mayer dalam Priansa (2014) komitmen organisasional ialah keyakinan yang mengikat perwakilan ke organisasi tempat mereka bekerja, yang ditunjukkan oleh ketergantungan mereka, inklusi pada pekerjaan, serta bukti nilai ataupun tujuan organisasi yang dapat dikenali. Allen dan Mayer dalam (Robbins S. , 2012) menyebutkan terdapat 3 komponen di dalam dimensi komitmen organisasional yaitu Affective Commitment ialah kuatnya keinginan seseorang dalam bekerja bagi organisasi atau perusahaan disebabkan karena dia setuju dengan tujuan-tujuan organisasi tersebut dan 
ingin melakukannya. Continuance Commitment ialah kuatnya keinginan seseorang dalam melanjutkan pekerjaannya bagi organisasi disebabkan karena dia membutuhkan pekerjaan tersebut dan tidak dapat melakukan pekerjaan yang lain. Normative Commitment ialah kuatnya keinginan seseorang dalam melanjutkan pekerjaan pekerjaan bagi organisasi disebabkan karena dia merasa berkewajiban dari orang lain untuk dipertahankan.

\section{RELIGIUSITAS}

Menurut (Daradjat, 2014) religiusitas merupakan proses hubungan manusia yang dirasakan terhadap sesuatu yang diyakininya bahwa terdapat sesuatu yang lebih tinggi dari pada manusia. Berdasarkan Glock \& Stark (dalam Ancok \& Suroso, 2001) dimensi religiusitas terbagi menjadi 5 jenis yakni : (1) Dimensi keyakinan, dengan indikator yaitu kepercayaan kepada Allah SWT, kepercayaan kepada malaikat, kepercayaan kepada rasul, kepercayaan kepada kitab-kitab Allah SWT, kepercayaan pada hari kiamat, kepercayaan pada qadha dan qadar (2) Dimensi praktik agama, dengan indikator yaitu melaukan shalat lima waktu, puasa di bulan ramadhan, selalu berdoa dan berdzikir kepada Allah SWT, membaca al-qur'an (3) Dimensi pengalaman, dengan indikator yaitu merasa dekat dengan Allah SWT, merasa doanya sering dikabulkan, merasa mendapat pertolongan dari Allah SWT, bertawakal kepada Allah SWT, dan merasa bersyukur kepada Allah SWT (4) Dimensi pengetahuan agama, dengan indikator yaitu ilmu tentang kandungan Al-Qur'an, ilmu tentang hukum-hukum dalam Islam, ilmu tentang rukun Islam, ilmu sejarah Islam, dan (5) Dimensi konsekuensi, dengan indikator yaitu perilaku suka menolong atau beramal, sabar, pemaaf, mentaati norma-norma ajaran Islam. Hasil penelitian (Halik, 2016) menyatakan bahwa religiusitas berpengaruh positif terhadap komitmen organisasional. Demikian juga hasil penelitian yang dilakukan oleh (Nudiya \& Budiman, 2018) menyatakan religiusitas berpengaruh positif terhadap komitmen organisasional.

Hipotesis 1 : Religiusitas berpengaruh positif terhadap komitmen organisasional

\section{KOMPETENSI}

Kompetensi ialah sebuah potensi dalam melakukan ataupun melaksanakan sebuah pekerjaan ataupun penugasan berdasarkan kemampuan dan informasi dan didorong oleh sikap kerja yang diterima oleh pekerjaan itu (Wibowo, 2014). Sementara itu, sependapat dengan (Spencer \& Spencer, 1993) kompetensi dapat menjadi karakteristik yang mendasari seorang individu serta berhubungan dengan kecukupan pelaksanaan seseorang pada pekerjaannya. Sependapat dengan Spencer \& Spencer (dalam Kandula R., 2013), kompetensi bisa dibedakan dalam 2 jenis, yakni kompetensi dasar (Edge Competency) serta kompetensi pemisah (Separating Competency). Dua jenis itu dikelompokkan ke dalam pengambilan setelah pengukuran dan penanda: (1) Proses berpikir (2) Karakteristik (3) Konsep Diri (4) Informasi, dan (5) Kemampuan. Hasil penelitian (Lotunani, 2014), (Sriekaningsih, 2015) menyatakan bahwa kompetensi memiliki pengaruh positif dan signifikan terhadap komitmen organisasional, demikian juga (Fadli, 2012) menyatakan bahwa kompetensi berpengaruh positif dan signifikan terhadap komitmen organisasional.

Hipotesis 2 : Kompetensi berpengarus positif terhadap Komitmen Organisasional

\section{BUDAYA ORGANISASI}

Budaya organisasi ialah kecenderungan yang terus-menerus dilakukan pekerja untuk mematuhi kontrol perusahaan, tetapi tidak semua masyarakat organisasi sama di setiap perusahaan. Sependapat dengan (Wibowo, 2013) budaya organisasi adalah nilai-nilai serta standar bersama yang ada pada sebuah organisasi serta mendidik para pekerja yang hadir. Definisi ini mengusulkan bahwasanya budaya organisasi terkait kepercayaan serta sentimen bersama, aturan pada perilaku serta bentuk yang dapat diverifikasi untuk mentransmisikan nilai dan standar. Berikut adalah dimensi budaya organisasi berdasarkan Robbins dan Judge (2015) : (1) Pengembangan dan pengambilan bahaya (2) Pertimbangan terhadap detail (3) Muncul tentang pengenalan (4) Pengenalan individu (5) Pengenalan kelompok (6) Kekuatan, dan (7) Kemantapan. Hasil penelitian (Mahmudah, 2012) dan (Arifin, 2010) menyatakan bahwa adanya hubungan positif antara budaya organisasi dengan komitmen organisasional. Demikian juga (Dwivendi, 2014) menyatakan bahwa budaya organisasi berpengaruh positif terhadap komitmen organisasional.

Hipotesis 3 : Budaya organisasi berpengaruh positif terhadap komitmen organisasional 
Berdasarkan hubungan antar variabel tersebut disusun Model Grafis sebagai berikut :

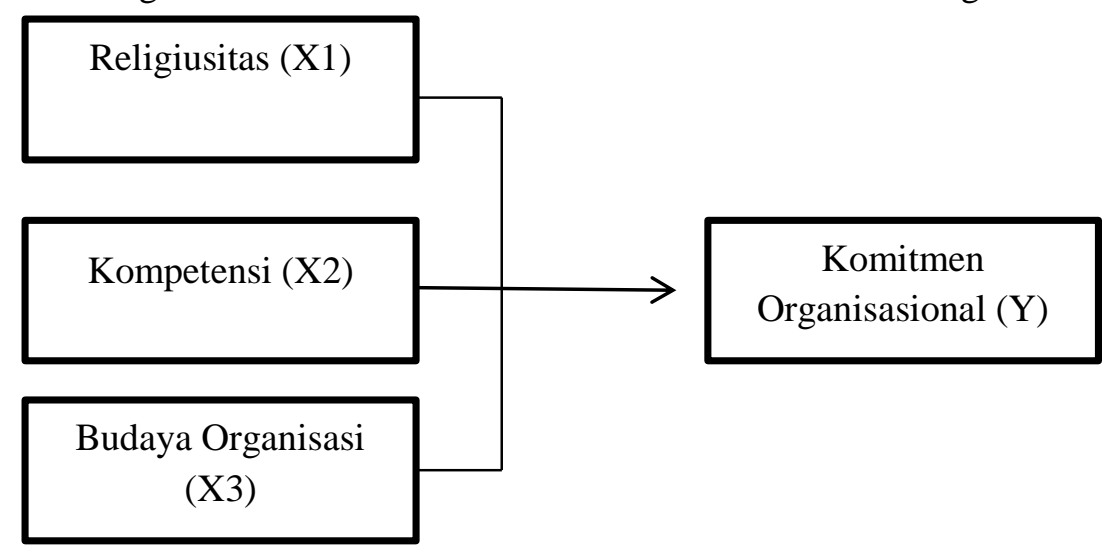

\section{Gambar 1. Model Grafis}

\section{METODE PENELITIAN}

Populasi pada penelitian ini ialah karyawan muslim PDAM Tirta Moedal Jl. Kelud Raya Kota Semarang yang jumlahnya 222 karyawan. Teknik pengambilan sampel pada penelitian ini ialah teknik simple random sampling. Berdasarkan Sugiyono (2017:82) teknik simple random sampling ialah Suatu cara yang mendasar karena pemeriksaan terhadap individu-individu dari suatu populasi dilakukan secara sembarangan tanpa melihat dan memperhatikan persamaan-persamaan atau strata yang ada di dalam populasi tersebut. Menggunakan rumus Slovin diperoleh $n=222 /\left(1+222(0,1)^{2}\right)=68$ karyawan dibulatkan menjadi 100 karyawan.

Jenis dan sumber data yang digunakan adalah data primer. Data primer yakni sumber data yang langsung memberikan informasi kepada responden. Data primer yang digunakan pada penelitian ini didapat dari kuesioner (Sugiyono, 2012). Kuesioner yang dilakukan pada penelitian ini adalah kuesioner tertutup. Kuesioner tertutup ialah peneliti sudah menyediakan pilihan jawaban dan responden tinggal memilih yang sesuai dengan kondisi yang sedang dialaminya (Arikunto, 2010). Alasan memilih kuesioner tertutup yaitu hasilnya mudah diolah dengan menggunakan komputer, responden tidak perlu menulis atau mengekspresikan pikirannya dalam bentuk tulisan, dan mengisi kuesioner tertutup tidak memerlukan banyak waktu. Metode analisis data pada penelitian ialah dengan menerapkan regresi linier berganda. Analisis regresi linier berganda bertujuan supaya mengetahui pengaruh variabel bebas secara bersama- sama terhadap variabel terikat. Perhitungan analisis regresi linier berganda pada penelitian ini dibantu dengan program SPSS 23.

\section{HASIL DAN PEMBAHASAN \\ HASIL UJI VALIDITAS}

Uji validitas dimaksudkan dalam mengukur sah ataupun valid tidaknya sebuah kuesioner. Sebuah kuesioner disebut valid apabila pertanyaan dalam kuesioner bisa menerangkan sesuatu yang akan diukur oleh kuesioner tersebut (Ghozali, $2018: 51$ ).

Berdasarkan olah data diketahui bahwa semua variabel telah memenuhi kecukupan sampel karena memiliki nilai KMO > 0,05 dan semua item dalam indikator variabel variabel religiusitas, kompetensi, budaya organisasi dan komitmen organisasional adalah valid karena memiliki nilai loading factor $>0,04$.

\section{HASIL UJI RELIABILITAS}

Berdasarkan hasil olah data diketahui bahwa variabel religiusitas (X1), kompetensi (X2), budaya organisasi (X3), dan komitmen organisasional (Y) mempunyai nilai cronbach's alpha lebih dari 0,70 , sehingga seluruhnya reliabel. 


\section{HASIL ANALISIS REGRESI LINIER BERGANDA}

Hasil Uji Regresi disajikan dalam tabel dibawah ini :

\begin{tabular}{|c|c|c|c|c|c|c|}
\hline \multirow[b]{3}{*}{ Persamaan } & \multicolumn{5}{|c|}{ abel 1 Hasil Uji Regresi } & \multirow[b]{3}{*}{ Ket } \\
\hline & \multicolumn{3}{|c|}{ Uji Model } & \multicolumn{2}{|c|}{ Uji t } & \\
\hline & $\begin{array}{l}\text { Adjusted } \\
\text { R Square }\end{array}$ & $\begin{array}{c}\text { F } \\
\text { Hitung }\end{array}$ & Sig & Beta & Sig & \\
\hline $\begin{array}{l}Y=\beta 1 X 1+\beta 2 X 2 \\
+\beta 3 X 3+e\end{array}$ & 0,665 & 54,589 & 0,000 & & & \\
\hline $\mathrm{X} 1 \longrightarrow \mathrm{Y}$ & & & & 0,058 & 0,387 & H1 ditolak \\
\hline $\mathrm{X} 2 \longrightarrow \mathrm{Y}$ & & & & 0,235 & 0,004 & $\mathrm{H} 2$ diterima \\
\hline $\mathrm{X} 3 \longrightarrow \mathrm{Y}$ & & & & 0,657 & 0,000 & H3 diterima \\
\hline
\end{tabular}

Sumber : data primer diolah tahun 2021

Berdasarkan Tabel 1 dapat dijelaskan sebagai berikut :

1. Pengaruh Religiusitas terhadap Komitmen Organisasional

Hasil analisis regresi berganda variabel religiusitas (X1) terhadap komitmen organisasional (Y) menunjukkan nilai Beta sebesar 0,058 dengan tingkat signifikasi $0,387>0,05$. Hal ini menunjukkan bahwasanya religiusitas tidak berpengaruh terhadap komitmen organisasional.

2. Pengaruh Kompetensi terhadap Komitmen Organisasional

Hasil analisis regresi berganda variabel kompetensi (X2) terhadap komitmen organisasional (Y) menunjukkan nilai Beta sebesar 0,235 dengan tingkat signifikasi 0,004 $<0,05$. Hal ini menunjukkan bahwasanya kompetensi berpengaruh positif serta signifikan terhadap komitmen organisasional. Jadi semakin baik kompetensi, sehingga akan semakin meningkatkan komitmen organisasional.

3. Pengaruh Budaya Organisasi terhadap Komitmen Organisasional

Hasil analisis regresi berganda variabel budaya organisasi (X3) terhadap komitmen organisasional (Y) menunjukkan nilai Beta sebesar 0,657 dengan tingkat signifikasi 0,000 < 0,05 . Hal ini menunjukkan bahwasanya budaya organisasi berpengaruh positif dan signifikan terhadap komitmen organisasional. Sehingga semakin baik budaya organisasi dalam suatu institusi, maka akan semakin meningkatkan komitmen organisasional.

\section{Koefisiensi Determinasi $\left(\mathbf{R}^{2}\right)$}

Berdasarkan tabel 1 diketahui bahwa Adjusted $R$ Square sebesar 0,665 artinya bahwa variabel religiusitas, kompetensi, dan budaya organisasi mampu menjelaskan komitmen organisasional sebesar $66,5 \%$, sementara sisanya $(100 \%-66,5 \%=33,5 \%)$ dijelaskan oleh variabel lain yang tidak diteliti.

\section{Uji F}

Berdasarkan Tabel 1, diketahui nilai signifikansi (sig) pada uji F sebesar $0,000<0,05$, hal ini menunjukkan bahwa religiusitas (X1), kompetensi (X2), dan budaya organisasi (X3) berpengaruh secara simultan terhadap komitmen organisasional (Y), sehingga model regresi pada penelitian ini dinyatakan layak untuk dianalisis lebih lanjut.

\section{Uji t}

Uji hipotesis pada penelitian dengan membandingkan nilai signifikansi dengan $\alpha$ yang digunakan (5\%). Berdasarkan hasil uji hipotesis pada Tabel 4, bisa dijelaskan sebagai berikut :

1. Hipotesis 1 : Religiusitas berpengaruh positif terhadap Komitmen Organisasional Berdasarkan Tabel 1, diketahui bahwa nilai beta pengaruh Religiusitas terhadap Komitmen Organisasional sebesar 0,058 dengan signifikansi 0,387>0,05. Hal ini berarti secara parsial (individu) tidak terdapat pengaruh antara religiusitas (X1) terhadap komitmen organisasional (Y). Oleh karena itu, hipotesis pertama ditolak. 
2. Hipotesis 2 : Kompetensi berpengaruh positif terhadap Komitmen Organisasional Dari Tabel 1, diketahui bahwa nilai beta pengaruh Kompetensi terhadap Komitmen Organisasional sebesar 0,235 dengan nilai signifikansi $0,004<0,05$. Hal ini berarti secara parsial (individu) Kompetensi (X2) berpengaruh pengaruh positif dan signifikan antara kompetensi (X2) terhadap komitmen organisasional (Y). Oleh karena itu, hipotesis kedua diterima.

3. Hipotesis 3 : Budaya Organisasi berpengaruh positif terhadap Komitmen Organisasional Berdasarkan Tabel 1, diketahui bahwa nilai beta berpengaruh Budaya Organisasi terhadap Komitmen Organisasional sebesar 0,657 dengan nilai signifikansi 0,000 $<0,05$. Hal ini berarti secara parsial (individu) budaya organisasi berpengaruh positif dan signifikan terhadap komitmen organisasional (Y). Oleh karena itu, hipotesis ketiga diterima.

\section{PEMBAHASAN}

\section{Pengaruh Religiusitas Terhadap Komitmen Organisasional}

Hasil penelitian menunjukkan bahwa religiusitas tidak berpengaruh terhadap komitmen organisasional. Bahwa tinggi rendahnya tingkat religiusitas di PDAM Tirta Moedal Jl. Kelud Raya Kota Semarang tidak mempengaruhi perilaku komitmen organisasional. Hal ini dikarenakan para karyawan mempercayai bahwa religiusitas adalah suatu keyakinan terhadap agamanya yang merupakan suatu kewajiban yang harus mereka miliki, sedangkan komitmen organisasional berkaitan dengan keterlibatan kerja dan loyalitas organisasi. Hasil penelitian ini didukung oleh Isnaini (2018) yang menyatakan bahwa religiusitas tidak memiliki pengaruh signifikan terhadap komitmen organisasional. Karena komitmen karyawan memang sudah terbangun dan terpisah dengan religiusitas itu sendiri.

\section{Pengaruh Kompetensi Terhadap Komitmen Organisasional}

Hasil penelitian menunjukkan bahwa kompetensi berpengaruh positif dan signifikan terhadap komitmen organisasional. Jadi semakin baik tingkat kompetensi yang dimiliki oleh karyawan maka dapat meningkatkan kinerja karyawan pada PDAM Tirta Moedal Jl. Kelud Raya Kota Semarang. Dilihat dari pendidikan responden maka responden dengan pendidikan sarjana mempunyai porsi dominan yaitu sebanyak $63.4 \%$. Tingkat pendidikan pada level sarjana menunjukkan bahwa unsur pengetahuan dari bagian kompetensi sangat menunjang kemampuan pegawai dalam menganalisis, memahami dan memecahkan masalah pekerjaannya. Hal inilah yang menjadi hal yang kuat dalam menyumbang tingkat penyelesaian pekerjaan, sehingga kinerjanya meningkat. Sebagian besar responden juga di dominasi dengan status menikah. Ini juga berkontribusi menimbulkan motivasi internal dengan berusaha bekerja keras dengan harapan akan mendapatkan reward dari instansi. Dengan imbalan yang menarik inilah yang mampu meningkatkan komitmen organisasional pegawai. Hasil penelitian ini sejalan dengan temuan studi yang dilakukan Yusuf (2013) dan (Lotunani, 2014) menyatakan bahwa kompetensi berpengaruh positif dan signifikan terhadap komitmen organisasional. Demikian pula hasil studi oleh (Fadli, 2012) dan (Sriekaningsih, 2015) yang menyatakan bahwa kompetensi berpengaruh positif dan signifikan terhadap komitmen organisasional. Para karyawan yang memiliki kompetensi yang lebih baik mampu meningkatkan kinerja dan komitmen organisasional.

\section{Pengaruh Budaya Organisasi Terhadap Komitmen Organisasional}

Hasil penelitian menunjukkan bahwa budaya organisasi mempunyai pengaruh terhadap komitmen organisasional. Hal ini menunjukkan bahwa jika budaya organisasi semakin meningkat maka akan meningkat pula komitmen organisasional pada PDAM Tirta Moedal Jl. Kelud Raya Kota Semarang. Hal tersebut berimplikasi pada tindakan yang hendaknya diambil olek pihak manajemen dalam rangka meningkatkan komitmen organisasional. Salah satu ciri budaya kuat adalah diikuti oleh sebagian besar karyawan dan menimbulkan komitemn organisasional (Sigit, 2013). Budaya organisasi yang mendukung komitmen organisasional adalah adanya fasilitas kerja yang memadai dan kenyamanan dalam bekerja. Oleh karenanya pihak manajemen perlu memperhatikan hal tersebut juga meningkatkan budaya organisasi yang masih kurang diberikan oleh institusi yaitu fasilitas rekreasi setiap tahun dan memperhartikan keseimbangan antar pekerjaan dengan kehidupan pribadi karyawan. Penelitian ini didukung oleh Putu (2019) dan (Arifin, 2010) bahwa ada hubungan positif antara budaya 
organisasi terhadap komitmen organisasional. Selain itu juga menurut (Dwivendi, 2014) dan (Mahmudah, 2012) budaya organisasi mempunyai pengaruh positif terhadap komitmen organisasional.

\section{KESIMPULAN}

Dari hasil penelitian serta pembahasan diperoleh kesimpulannya yakni :

1. Religiusitas tidak berpengaruh terhadap komitmen organisasional, karena karakter responden yang sebagian besar sarjana sudah pada tingkat matang dalam beragama sehingga tidak lagi menjadi faktor yang berpengaruh terhadap komitmen organisasional karena faktor religiusitas adalah hubungan mereka dengan Tuhannya.

2. Kompetensi berpengaruh positif serta signifikan terhadap komitmen organisasional, artinya semakin baik kompetensi yang dimiliki karyawan maka semakin tinggi komitmen organisasional pada PDAM Tirta Moedal Jl. Kelud Raya Kota Semarang.

3. Budaya Organisasi berpengaruh positif serta signfikan terhadap komitmen organisasional, artinya bahwa semakin baik budaya yang diterapkan organisasi maka semakin tinggi komitmen organisasional karyawan.

\section{SARAN}

Saran Praktis:

- Memperbaiki budaya organisasi yang dipandang masih kurang oleh karyawan yaitu memberikan fasilitas rekreasi setiap tahun dan memberikan perhatian terhadap kehidupan pribadi karyawan, sehingga karyawan mempunyai waktu yang cukup untuk keluarganya.

- Meningkatkan kompetensi karyawan dengan cara memberi kesempatan kepada karyawannya menyampaikan gagasan-gagasannya untuk kemajuan institusi dan memberikan kesempatan pada karyawan memimpin dalam suatu tim kerja untuk melatih leadershipnya.

\section{Saran Teoritis:}

- Pada penelitian ini yakni untuk peneliti selanjutnya disarankan untuk dapat lebih menggali teori-teori yang relevan untuk dipakai dalam penelitian, khususnya tentang pengaruh religiusitas, kompetensi dan budaya organisasi terhadap komitmen organisasional.

\section{REFERENSI}

Adhi, P. (2016). Pengaruh Kompetensi Dan Pengembangan Karir Terhadap Kepuasa Kerja Dengan Komitmen Organisasional Sebagai Variabel Mediasi. Bisnis dan Ekonomi, Vol. 23, No. 2 : 1412-3126.

Ancok, \& Suroso. (2001). Psikologi Islami. Yogyakarta: Pustaka Belajar.

Arifin, N. (2010). Analisis Budaya Organisasional Terhadap Komitmen Kerja Karyawan Dalam Peningkatan Kinerja Organisasional Karyawan Pada Koperasi BMT Di Kecamatan Jepara. Jurnal Ekonomi dan Pendidikan, 8(2):173-192.

Arikunto. (2010). Prosedur Penelitian Suatu Pendekatan Praktik. Jakarata: Rineka Cipta.

Daradjat, Z. (2014). Metode Khusus Pengajaran Agama Islam. Jakarta: Bumi Aksara.

Dwivendi. (2014). Impact og Organizational Culture on Commitment of Employees : An Empirical Study of BPO Sector in India. Business Process Outsourcing, 39(3):77-92.

Fadli, U. (2012). Pengaruh Kompetensi Kerja Pada PT PLN (Persero) Rayon Rengasdengklok. Jurnal Manajemen, Vol. 9, No. 2 Januari, 577-589.

Ghozali, I. (2018). Aplikasi Analisis Multivariate dengan Program SPSS 25. Semarang : Badan Penerbit Universitas Diponegoro.

Halik, A. (2016). Pengaruh Bauran Pemasaran Jasa, Kualitas Layanan, dan Nilai Religiusitas Terhadap Kepercayaan Nasabah dan Implikasinya Pada Komitmen Nasabah Bank Umum Syariah di Wilayah Gerbang Kertasusila Jawa Timur. JHP17 : Jurnal Hasil Penelitian LP4M Untag Surabaya, Vol. 1, No. 01, pp. 123-148.

Isnaini. (2018). Analisis Pengaruh Work Family Conflict, Religiusitas Terhadap Komitmen Organisasional Dan Kinerja Karyawan Dengan Variabel Intervening Kepuasan Kerja Pada Bank Syariah Di Yogyakarta. Yogyakarta: Universitas Islam Indonesia. 
Kandula R., S. (2013). Competency Based Human Resource Management : A Complette Text With Case Studies on Competency Mapping, Modelling, Assessing and Applying. Bangalore, Delhi: Gtae Corporation.

Lajim, S., Shamsuddin , N., \& Bohari, M. (2015). Impact Of Religiosity Towards Organizational Commitment : A Case Of Banking Institutions In Mukah, Sarawak. Kuala Lumpur, Malaysia: In Proceedins of 22nd ISERD International Conference.

Lotunani, A. (2014). The Effect of Competence on Commitment, Performance and Satisfaction with Reward as a Moderating Variable (A Study on Designing Work plans in Kendari City Goverenment, Southeast Sulawesi). International Journal of Business and Management Invention, Volume 3 Issue 2, February, 18-25.

Luthans, F. (2011). Organizational Behavior. New York: McGraw_Hill Company.

Mahmudah, E. (2012). Effects of organizational culture and ability on organizational commitment and performance in Ibnu Sina hospital, Gresik. Academic Research International, 2 (1), 349-355.

Marwansyah. (2016). Manajemen Sumber Daya Manusia. Bandung: Alfabeta.

Nudiya, S., \& Budiman, A. (2018). Hubungan Antara Religiusitas dengan Komitmen Organisasio Pada Guru di Pesantren Baiturrahman Bandung. Jurnal Manajemen, ISSN : 2460-6448, Vol. 8, No.2.

Priansa, D. (2014). Perencanaan dan Pengembangan Sumber Daya Manusia. Bandung: Alfabeta.

Puji, A. (2012). Pengaruh Kompetensi, Self Efficacy Terhadap Kinerja Guru Dimediasi Komitmen Organisasional (Studi Guru SMP Negeri di Kabupaten Pati). Journal of Economic and Management, Vol. 1, No. 1.

Putu Enda, W. (2019). Pengaruh Budaya Organisasi Dan Dukungan Organisasi Terhadap OCB Dimediasi Oleh Komitmen Organisasional. Jurnal Manajemen, Vol. 8, No. 12.

Robbins, S. (2008). Perilaku Organisasi, Jilid I dan II, alih Bahasa . Jakarta: Prenhallindo.

Robbins, S., \& A. Judge, T. (2011). Organizational Behavior. New Jersey: Fourteenth Edition. Pearson education.

Robbins, S. (2012). Perilaku Organisasi. Jakarta: Salemba Empat.

Robbins, \& Judge. (2015). Perilaku Organisasi . Jakarta: Edisi 16. Salemba Empat.

Sigit, M. (2013). Penelitian Tindakan Kelas. Yogyakarta: Graha Ilmu.

Spencer, L., \& Spencer , M. (1993). Competence at Work, Models For Superior Performance. Canada: John Wiley \& Sons, Inc.

Sriekaningsih, A. (2015). The Effect of Competence and Motivation and Cultural Organization towards Organizational Commitment and Performance on State University Lecturers in East Kalimantan, Indonesia. European Journal of Business and Management, Vol. 7, No. 17, pp 208-219.

Sugiyono. (2012). Metode Penelitian Kuantitatif Kualitatif. Bandung: Alfabeta.

Sugiyono. (2017). Metode Penelitian Kuantitatif, Kualitatif, dan R\&D. Bandung: Alfabeta.

Sunhaji. (2014). Kualitas Sumber Daya Manusia (Kualifikasi, Budaya Organisasi Dan Sertifikasi Guru). Jurnal Kependidikan, Volume 2 (1): 142-160.

Wibowo. (2012). Manajemen Kinerja. Jakarta: Raja Grafindo Persada.

Wibowo. (2013). Perilaku dalam Organisasi. Jakarta: PT. Grafindo Persada.

Wibowo. (2014). Manajemen Kinerja. Jakarta: Raja Grafindo Persada.

Yusuf, Y. (2013). Pengaruh Tingkat Partisipasi Dalam Tim Kerja dan Kompetensi Terhadap Komitmen Organisasi Dengan Pemberdayaan Sebagai Variabel Pemediasi (Studi Kasus pada Dosen PTS di Banda Aceh). Jurnal Ekonomi Manajemen dan Bisnis, 1 (1), 1-26. 